\title{
Restorative Justice in Application for Crime Investigation on Property
}

\author{
Ragil Tri Wibowo ${ }^{1}$ and Akhmad Khisni ${ }^{2}$
}

Abstract. Restorative Justice or mediating a settlement out of court or in the absence of legal proceedings, a form of means to enforce the laws that promote justice for those who were litigants. In addition there is the meaning contained in the Restorative Justice or settlement out of court legal settlement that is the rapid acceleration by not leaving the rights of each party and in accordance with the laws of life (living law) which is part of the customs that exist in Indonesian society. However Restorative Justice and mediation in Indonesia there is no definite legal umbrella so that the rule of law has not regulated the process of implementation, but reality on the ground Restorative Justice or mediation process has been commonly carried out and have a positive impact. In the most preferred law enforcement is a sense of justice both the victim and of the perpetrator so that mediation between the parties is very influential in the settlement. In the implementation of Restorative Justice and mediation can only be carried out against the legal process done by children as offenders (minors) with Diversi term, but for other general criminal cases there are no rules that govern them. Restorative Justice and mediation have often carried out in developed countries, but in Indonesia there is no definite rules related to the implementation, therefore we are pushing for the parties berkompenten about the manufacture or preparation of regulations on the enforcement of the failure by a review of the application of Restorative Justice in common criminal case.

Keywords: Investigation; The Law Of Life; Restorative Justice.

\section{Introduction}

The law in Indonesia was basically created to organize and direct human behavior or society towards good, it ditangkan in law, written or unwritten. The law has consequences that must be accepted punishment for violators of the law itself, from social sanctions, penalties and even criminal sanctions to imprisonment of violators of the regulation.

The laws that apply in Indonesia has several sources before independence already in force, inter alia derived from religious law, the law derived from custom or habit, and laws are sourced from other countries who colonized Indonesia. The third source of law is very closely related, and none can be separated from each other, because if the state law enforced in the area which upholds the common law, the existence of the law itself will collide with the community. It is highly inversely proportional to the purposes of the law itself which creates organize and direct people to the better.

In the Constitution Constitution of the Republic of Indonesia in 1945 Chapter 1 Article 1, paragraph 3 is explained that "Indonesia is a State of Law", this indicates that everything that happens in Indonesia, both related to the state or the society arranged

\footnotetext{
${ }^{1}$ Student of Masters (S2) of Law Faculty of Law Unissula and Police Member Officer email: ragilzldsemarang@gmail.com

${ }^{2}$ Lecturer of Faculty of Law Unissula Semarang
} 
according to applicable legislation. It is formulated to limit the rights and obligations of society to society and the public on the state to ensuring fairness for the people of Indonesia.

In terms of law enforcement there is the expected goals of law enforcement, according to the law is enforced destinate Gustav Radbruch in order to achieve legal certainty, justice or expediency law on parties ${ }^{3}$, This is in accordance with the preamble to the Constitution of the Republic of Indonesia in 1945 and Pancasila in principle to the two that reads "just and civilized humanity ${ }^{4}$ "This case shows that law enforcement should also be the fulfillment of a sense of justice and humanity for the parties who are running the law enforcement process either victims or perpetrators.

Effective law enforcement by Lawrance M. Friedman, there are three elements include the substance of the law, the legal structure and culture or culture ${ }^{5}$, The substance of the law contains the rules and laws that are used to catch criminals. The legal structure contains institutions authorized to carry out the regulations and laws that would have to have good human resources. Kultur or Culture Society implies attitudes and behavior towards their law upheld in society, are the people classified as law-abiding society or not.

In terms of sociological problems being crowded at issue in Polrestabes Semarang is a suspicion of criminal fraud and embezzlement by the property as a loss. Where the process begins with a police action in the form of inquiry and investigation, it certainly takes time, thought, energy and costs, not infrequently a case would take a long time due to some fektor amtara A large number of related reporting cases of alleged fraud and embezzlement that had to wait queues and lack of investigators who are in units of Criminal Polrestabes semarang.

The problems that now thrive in the community that is the lack of unbelief of the public about the rule of law itself, the authors categorize three factors, among others, laws or regulations that are not relevant, there are unscrupulous law enforcers who have no soul as law enforcement, and the community now as do not bother with the laws that apply their own way. In addition there are other factors that make people less in response to the law of justice obtained after the trial did not match expectations for both victims and perpetrators,

Therefore, the authors have an interest in reviewing the concept of Restorative Justice to be applied in order to obtain justice. In this case the object is a crime against property as damages, which refund such losses become in fighting by the victim. Reviewing the legal regulations in force in Indonesia and the existing regulations in the Police related to the process implemented when cases reported resolved by way of Restorative Justice, as well as the steps made in relation to the implementation of the concept of Restorative justice can be carried out as well as see the role of law who live or Living Law which is still in hold dear by the people of Indonesia. Therefore, the

\footnotetext{
3 http://sharingaboutlawina.blogspot.co.id/2014/12/tujuan-hukum-menurut-gustav-radbruch.html accessed on Thursday March 222018 09:00 pm

${ }^{4}$ https://id.wikipedia.org/wiki/Pancasila accessed on Thursday March 222018 09:15 GMT.

${ }^{5}$ http://khoiruumah96.blogspot.co.id/2016/03/normal-0-false-false-false-en-us-x-none.html accessed on Thursday March 222018 09:14.
} 
author gives the title of this article "Restorative Justice in Implementation of Crime Investigation on Property.

The issues that will be reviewed by the authors in this paper is: How does the application of Restorative Justice in the investigation of criminal offenses against property in Polrestabes Semarang? Barriers to implementation of Restorative Justice in the investigation of criminal offenses against property in Polrestabes Semarang? How to implement a solution for Restorative Justice in the investigation of criminal offenses against property in Polrestabes Semarang?

\section{Research Methods}

This research approach using socio-juridical approach, the one studied in the beginning is the primary data, to then proceed with a study of secondary data in the field, or on society.

In addition to also gather data from secondary data such as documents or library materials. Secondary legal materials is closely related to primary legal materials and can help analyze and understand the primary legal materials that draft legislation scholars results of scientific work or research results. ${ }^{6}$

Specifications research is descriptive analysis, ie by describing the legislation in force associated with legal theories and practice of positive law concerning problems in this study, as this study aims to provide a detailed description, systematic and thorough, Which is associated with the legal theories and practices of law enforcement in Indonesia, namely by collecting data from interviews to the competent authorities and the study of literature on the laws that exist.

In this research for data collection techniques for analysis using direct interviews and document collection about Restorative justice legislation and implementation.

Data analysis techniques in the study of this research proposal is the data obtained through this study are presented descriptively, that is to describe, explain and illustrate in accordance with the problems closely associated with this research

Data analysis methods used are qualitative methods, data analysis done qualitatively, comprehensive and complete. The data analysis means to decipher the data quality in the sentence orderly, coherent, logical, non-overlapping and effectively so as to facilitate the interpretation of data and understanding of analytical results.

\section{Results and Discussion}

Restorative Justiceis an approach that emphasizes fairness and balance between the perpetrator / reported by the victim / complainant, which the sentencing process will be changed to the mediation process diaman all parties will have the right and obligation of a balanced and equal. Victim / aggrieved complainant will get the goods or loss they experienced while actors / Reported get a chance to resolve the issue without any legal process to go through, it also requires the other party as a mediator in the implementation of this Restorative Justice. According to Teguh Prasetyo theory

\footnotetext{
${ }^{6}$ Ronny Hanitijio Soemirto Metodologi Penelitian Hukum Dan Jurimetri (Jakarta : Ghalia Indoesia 1995) p. 12
} 
Dignity Justice against law enforcement in Indonesia with Restorative Justice or settling disputes outside the court whether it can create a breakthrough law enforcement and legal settlement that is right for today's society.

This concept provides protection against the perpetrator and the victim about the rights and obligations of each party, which are not mutually felt disadvantaged because losses have been returned or replaced in accordance with the agreement dihsilkan of each party, if already obtained an agreement then there is a sense of injustice of one of the litigants. The concept of the approach is from a variety of angles, religion, culture and the law itself.

Restorative Justice also an implementation of the implementation of customary law that already existed before the law of the country in shape and is enforced, where consensus becomes an enforcement process that can be accepted by people, where traditional oriental still felt in Indonesia.

In the discussion about the concept / system implementation of Restorative Justice, we must break down beforehand about the criminal justice system so that the concept / Restorative Justice system can be implemented. According Muladi, criminal justice system is a network judicial use of criminal law as a primary means, both material criminal law, formal law, and criminal law enforcement ${ }^{7}$,

Mardjono Reksodiputro explain limitations of the criminal justice system is crime control system consisting of institutions of police, prosecutors, courts and correctional $^{8}$,

Barda Nawawi Arief explained the criminal justice system is essentially identical to the criminal law enforcement system, or a system of judicial authority in the field of criminal law. The power system is divided into four (4) sub-system of power among other powers of investigation, prosecution powers, the power to hear / convict and power of execution / implementation of the criminal. As the criminal law enforcement system in the justice system there are aspects of substantive criminal law enforcement system, aspects of criminal law enforcement system and the formal aspects of implementing criminal law enforcement system ${ }^{9}$,

According to the Criminal Soedarto is suffering deliberately imposed on those who commit acts that meet certain conditions, so pidan itself is a result of acts committed by someone who is assessed or considered harmful to someone.

Based on the above opinion the opinion that the judicial system passed through their process in the Police Investigation, Prosecution attorney, and the court verdict and execution. The probe itself means a series of actions the investigator to determine whether there is a suspect in a crime. Thus, in the investigation process requires steps that must be passed, among others investigations, witness examination of witnesses, gathering evidence and his case to determine a suspect.

\footnotetext{
${ }^{7}$ Muladi 2002 Kapita Selekta Sistem Peradilan Pidana Semarang,: Badan Penerbit Universitas Diponegoro p.4

${ }^{8}$ Mardjono Reksodiputro 1993 " Sistem Peradilan Pidana Indonesia (Melihat kepada kejahatan dan penegakan hukum dalam batas-batas toleransi)" Pidato pengukuhan penerimaan jabatan guru besar tetap dalam ilmu hukum pada Fakultas Hukum Universitas Indonesia Jakarta p. 1

${ }^{9}$ Barda Nawawi Arief,2007 Kapita Selekta Hukum Pidana Tentang Sistem Peradilan Terpadu(Integrated Criminal Justice System) Semarang Badan Penerbit Universitas Diponegoro $p 9$
} 
In the process of investigation by the police to a crime, according to Muljatno offenses or better known as the criminal act is an act that is prohibited by a rule of law which the ban as well as threats in the form of a specific criminal, for anyone who violates the ban. This means that each of what a person who violates a prohibition set out in legislation that person may be punished according to the rules.

Law enforcement has the meaning of the implementation of the process or stages of a rule of the laws implemented by law enforcement officers with authority involving several parties are mutually bound. Enforcement of criminal law is an integral process begins with the investigation, arrest, detention, court accused and ends with correctional convicts ${ }^{10}$

In fact the field that becomes another issue is where the victim or the complainant wants the goods or loss suffered by the offender returned or reported that it has been made a victim or complainant considers the case is completed. In contrast to the process or stage in the investigation in which the police did not eliminate the indemnification of Crime. Therefore the application of Restorative Justice in the investigation process is indispensable in accelerating the completion of the problems / sengketadan the most important thing is to achieve justice terhaadap party litigants / dispute.

In light of the above authors try to decrease the problems confronted in accordance with existing rules. For Restorative justice obstacles in the implementation of the process of investigation of criminal matters, namely the lack of clear legal regulation and definitely related to the implementation of the Restorative justice. In developed countries have expanded the settlement with Restorative justice methods to reduce state expenditure and the implementation is quite fast because it is not through the legal process further.

Related obstacles in the implementation Restorative justice the possible solutions to be taken by the application of Restorative justice method revoke witness testimony that the evidence in accordance with the Criminal Procedure Code is reduced so that the case was not enough evidence and conducted SP3 of the case and the case can be solved or if the reporting and reported already has a collective agreement and are not concerned about the case can be revoked by the collective agreement.

\section{Closing}

\subsection{Conclusion}

Application of Restorative justice in the process of investigation of criminal offenses against property in Polrestabes Semarang can not be implemented to the fullest despite the customary and the litigants had agreed and does not mind, because of the rule of law that has been fixed and should be implemented, in practice the investigator can give input to carry out by pulling information from witnesses that there is less evidence and rules in article 184 of the Criminal Code is not fulfilled and carried his case to SP3.

\subsection{Suggestion}

\footnotetext{
${ }^{10}$ Harun M.Husen Kejahatan dan Penegakan Hukum Di Indonesia. Jakarta :Rineka Cipta. 1990 p. 58
} 
In this paper we provide input and advice regarding the application of Restorative justice in the investigation of an offense that is to be made a definite rule of law so that the investigator can be guided by the rules and be able to carry out the investigation process.

\section{References}

[1] Barda Nawawi Arief 2007 Kapita Selekta Hukum Pidana Tentang Sistem Peradilan Terpadu (Integrated Criminal Justice System) Semarang Badan Penerbit Universitas Diponegoro

[2] Harun M. Husen 1990 Kejahatan dan Penegakan Hukum Di Indonesia Jakarta Rineka Cipta.

[3] Khoiru Umah 30 Maret 2016 "Sistem Hukum Menurut M Friedmaan" http://khoiruumah96.blogspot.co.id/2016/03/normal-0-false-false-false-en-us- $x$ none.html, accessed on Thursday March 222018 09:14

[4] Mardjono Reksodiputro 1993 "Sistem Peradilan Pidana Indonesia (Melihat kepada kejahatan dan penegakan hukum dalam batas-batas toleransi)" Pidato pengukuhan penerimaan jabatan guru besar tetap dalam ilmu hukum pada Fakultas Hukum Universitas Indonesia Jakarta

[5] Muladi 2002 Kapita Selekta Sistem Peradilan Pidana Semarang Badan Penerbit Universitas Diponegoro

[6] Popuripur Dadap 8 Desember 2014 “Tujuan Hukum Menurut Gustav Rodbruch http://sharingaboutlawina.blogspot.co.id/2014/12/tujuan-hukum-menurutgustav-radbruch.html accessed on Thursday March 222018 09:00 pm

[7] Ronny Hanitijio Soemirto 1995 Metodologi Penelitian Hukum Dan Jurimetri (Jakarta : Ghalia Indoesia,)

[8] Wikipedia Bahasa Indonesia 12 Mei 2012 "Pancasila "https://id.wikipedia.org/wiki/Pancasila accessed on Thursday March 222018 09:15 hours GMT. 